\title{
Genetic parameters associated with tuber yield and tuber appearance traits of potatoes in early generations of selection
}

\author{
L.R. Terres ${ }^{1}$; E.A. Lenz $^{1 / *}$; F.F. Cima ${ }^{1}$; G.O. Silva ${ }^{2}$; A. da S. Pereira ${ }^{3}$
}

Received: $20 / 06 / 2016$

Accepted: 15/07/2016

Accessible on line: December 2016

\section{Summary}

The knowledge of genetic parameters of traits, in early generation selection, is important for breeding programs to define strategies and obtain success. The objective of this study was to estimate genetic parameters of yield components and tuber appearance traits in early selection generations of potatoes and their implications in the selection process. Twelve segregating potato families originated from crosses between two groups of parents of the Embrapa potato breeding program were evaluated. Group 1 was formed by foreign potato parents: Pukara, Asterix, Rioja, and Caesar; and group 2, by national parents: Eliza, C1730-07-94, and C175015-95. The experiment was conducted in autumn seasons of 2012 and 2013. A randomized complete block design with three replications was used. Considering all traits together, Pukara/Eliza, Asterix/Eliza, and Rioja/Eliza families had the highest means on a large number of tuber appearance and yield traits. The results of this study suggest that selection may be applied with mild to moderate intensity in the seedling generation for skin texture, tuber general appearance, tuber number, average tuber weight and total tuber yield, based on the moderate to high heritability estimated on the seedling generation. The highest selection gains were for skin texture, tuber general appearance, tuber number, average tuber weight and total tuber yield.

Additional key words: Solanum tuberosum L., seedling generation, heritability.

\section{Parâmetros genéticos associados a caracteres de aparência e rendimento de tubérculos de batata em gerações iniciais de seleção}

\section{Resumo}

O conhecimento de parâmetros genéticos dos caracteres em gerações iniciais de seleção é importante para que programas de melhoramento definam suas estratégias e com isso, obtenham sucesso. O objetivo do presente trabalho foi estimar parâmetros genéticos de caracteres componentes de rendimento e de aparência de tubérculos de batata nas primeiras gerações de seleção e suas implicações no processo de seleção. Foram avaliadas 12 famílias segregantes de batata, originadas de cruzamentos entre dois grupos de genitores. $\mathrm{O}$ grupo 1 foi formado pelos genitores estrangeiros: Pukara, Asterix, Rioja e Caesar; e o grupo 2, pelos genitores nacionais: Eliza, C1730-07-94 e C1750-15-95. O experimento foi realizado nas

\footnotetext{
* Corresponding author. Electronic mail: arione.pereira@embrapa.br

${ }^{1}$ Universidade Federal de Pelotas/ Faculdade de Agronomia Eliseu Maciel/ Programa de Pós-graduação em Agronomia - Pelotas, RS, Brasil.

${ }^{2}$ Embrapa Hortaliças - Canoinhas, SC, Brasil.

${ }^{3}$ Embrapa Clima Temperado - Pelotas, RS, Brasil.
} 
safras de outono de 2012 e 2013, em delineamento de blocos ao acaso, com três repetições. Considerando, conjuntamente, os resultados de todos os caracteres, destacaram-se as famílias de Pukara/Eliza, Asterix/Eliza e Rioja/Eliza, por apresentarem as melhores médias, em um maior número de caracteres de aparência e rendimento de tubérculo. Os resultados encontrados neste estudo sugerem que se pode aplicar seleção, com intensidade de leve a moderada, na geração de plântula para os caracteres textura de película, aparência geral de tubérculo, número, massa e massa média de tubérculos, com base nas estimativas de herdabilidade moderada à alta, obtidas na geração de plântula. Os maiores ganhos de seleção para estes caracteres foram nos caracteres textura de película, aparência geral de tubérculo, número, massa e massa média de tubérculos.

Palavras-chave adicionais: Solanum tuberosum L., geração de plântula, herdabilidade.

\section{Introduction}

Most of the potato produced in Brazil goes to fresh market, where tuber appearance is the key factor for marketing. The Brazilian consumers prefer smooth and glossy tuber skin, especially of yellow skin tuber cultivars (Pereira and Daniels, 2003).

In potato breeding, more than 40 traits are involved in the selection process (Gebhardt et al., 2007). In this sense, the development of new cultivars must consider many traits simultaneously. To identify superior clones in the selection process breeders need to assess, on the whole, the appearance and tuber yield traits (Melo, 1999).

Tuber appearance and tuber yield are complex traits, composed of a number of simpler traits, thus presenting low heritability (Tai and Young, 1984). However, their component traits present genetic parameter estimates of greater magnitude, enabling more efficient selection (Silva et al., 2008a). Skin texture and skin color are the most important tuber appearance traits, whereas tuber number and average tuber weight are the most important tuber yield traits, presenting higher heritability estimates (Gopal et al., 1994; Rodrigues and Pereira, 2003; Silva et al., 2008a).

As for the selection in early generations, which depends on trait expressions in smaller and less tubers, some authors attribute low efficiency (Brown et al.,

1984; Pinto et al., 1999; Gopal et al., 1994), while others believe that it is possible to make negative selection for some traits (Bisognin and Douches, 2002; Xiong et al., 2002; Silva et al., 2008b). The elimination of inferior genotypes as soon as possible, through the selection in early generations, prevents inferior genotypes to be maintained in the field, reducing costs by using less inputs, planting area and labor (Silva et al., 2011).

The aim of this study was to estimate genetic parameters for tuber yield and tuber appearance traits, in early generations of selection, and its implications in the selection process.

\section{Materials and methods}

Experiments were conducted in the experimental field of Embrapa Temperate Agriculture, in Pelotas, RS, Brazil $\left(31^{\circ} 40^{\prime} 18^{\prime \prime} \mathrm{S}, 52^{\circ} 26^{\prime} 15^{\prime \prime} \mathrm{W}\right.$, and 60 m.a.s.l.). The Podzolic red-yellow soil type was fertilized at planting time with $100 \mathrm{~N}$, $600 \mathrm{P}_{2} \mathrm{O}_{5}$ and $200 \mathrm{~K}_{2} \mathrm{O} \mathrm{kg} \mathrm{ha}{ }^{-1}$. Twelve potato segregating families, originated from crossings between two parent groups were used in the study: Group 1, formed by foreign parents: 'Pukara', 'Asterix', 'Rioja', and 'Caesar'; Group 2, with 
Brazilian parents: 'Eliza', 'C1730-7-94', and 'C1750-15-95'.

In autumn of 2012, the seedling generation was grown in plastic, screen-house Sexual seeds were germinated in wooden boxes and seedlings were transplanted to $2 \mathrm{~L}$ plastic bags, filled with commercial substrate (peat added with $0.04 \% \mathrm{~N}, 0.04$ P2O5, and 0.05\%). Seedlings were distributed in a randomized complete block design with three replications. Each plot consisted of a 25 seedling sample, randomly taken, at the time of transplanting, to represent each family. Seedlings were spaced $0.10 \mathrm{~m}$, within and between lines. Eighty days after transplanting, tubers were harvested, identified and transported to appropriate facilities.

Tubers were evaluated immediately after harvesting. For tuber appearance traits, the evaluations followed scales of nine classes as: skin texture (1- rough, 9- smooth), eye depth (1- deep, 9- shallow), eyebrow prominence (1- prominent, 9- not prominent), shape (1- round, 9- elongated), size uniformity (1- uneven, 9- uniform), pointing (1- pointed, 9- not pointed), curvature (1- curved, 9- not curved), flattening (1- flattened, 9- not flattened), size (1- small, 9- large), and overall appearance (1- very poor, 9- excellent). Good-looking tubers were considered those which presented smooth skin, shallow eyes, not prominent eyebrow, uniform shape, not pointed, not curved, not flattened, and uniform size (Silva et al., 2014).

Tuber yield traits were evaluated as: number of tubers per plant, total mass of tubers per plant, and average tuber weight.

After evaluations, tubers were stored in cold storage at $4^{\circ} \mathrm{C}$ to be used as seed for the first field generation experiment, which was conducted in the autumn season of 2013. For this experiment three medium-sized tubers of each genotype were planted in the field, forming the experimental unit, and using the same experimental design of the seedling generation. Again, the plots were evaluated immediately after harvesting, following the same criteria.

The data were tested for normality of residuals using the Lilliefors test. Subsequently, the data of each generation were submitted to analysis of variance and means were grouped by the Scott and Knott test at 5\% error probability, using the Genes statistical package (Cruz, 2013).

For the analysis of variance, the statistical model used was as follows (Cruz and Regazzi, 2001):

$\mathrm{Y}_{\mathrm{ij}}=\mu+\mathrm{g}_{\mathrm{i}}+\mathrm{e}_{\mathrm{ij}}$, for families,

where $Y_{i j}$ is the observation on the ith genotype in the jth block; $\mu$ is the overall mean; $g_{i}$ is the random effect of the ith genotype confounded with environment effects; $e_{i j}$ is the experimental error associated to $\mathrm{Y}_{\mathrm{ij}}$ observation.

Variance components and heritability were estimated according to Vencovsky and Barriga (1992), by the formula:

$$
h^{2}=\frac{\sigma^{2} \mathrm{~g}}{\sigma^{2} \mathrm{~g}+\sigma^{2} \mathrm{e}+\mathrm{r}},
$$

where $\sigma^{2} \mathrm{~g}$ is the genetic variance, $\sigma^{2} \mathrm{e}$ is the error variance and $r$ is the number of replications.

The selection gain (GS), at $10 \%$ selection intensity, was calculated according to the formulae:

$\mathrm{GS}_{\mathrm{i}}=\mathrm{k} \sigma_{\mathrm{gi}} \mathrm{h}_{\mathrm{i}}$,

where $\mathrm{k}$ is the selection intensity, $\sigma_{\mathrm{gi}}$ is the genetic standard deviation of the trait and $\mathrm{h}_{\mathrm{i}}$ is the heritability (Cruz, 2006).

\section{Results and Discussion}

The normality of the data of the seedling generation and of the first field generation showed non-normal error distribution for eye depth and tuber flattening, even after transformation; therefore, these two traits 
were taken out of further statistical analyzes.

The joint analysis of variance of the two generations detected significant family $\mathrm{x}$ generation interaction $(p<0.05)$ for skin texture, tuber shape, overall tuber appearance, uniformity of tuber size, tuber number, tuber yield and average tuber weight (Table 1). Interactions for yield component traits might be ascribed to differences in the size and number of tubers produced by the generations. For eyebrow prominence, uniformity of tuber shape, tuber pointing, tuber curvature, and tuber size, there were significant differences only generation.

Coefficients of variation were in agreement with those reported by Silva et al. (2007) and Veríssimo et al. (2012), in studies of seedling and first generations of selection (Table 1). According to Carvalho et al. (2004), the coefficient of variation is a relative measure of dispersion. It is of great use for comparison, in relative terms, the degree of concentration around the average, giving an idea of the experimental precision, and can be classified as low $(<10 \%)$, medium $(10-20 \%)$, high (20$30 \%)$, and very high $(>30 \%)$.

The $\mathrm{CVg} / \mathrm{CVe}$ ratio (genetic coefficient of variation/ environmental coefficient of variation) assumed values greater than one for tuber number and average tuber weight, which are considered optimum for selection (Cruz and Carneiro, 2006) (Table 1). For other traits, the ratio was less than unity, showing great influence of the environment at the expense of genetic variation.

Comparing coefficients of variation of the group which showed significant family per generation interaction, it can be observed that all traits showed lower values in the first field generation than in the seedling generation (Table 2). This is indicative of greater experimental precision in the first field generation, and can be attributed to larger tuber size and number in this generation than in the seedling generation, which allows a better evaluation of these traits. In the seedling generation, the plant growth and tuber development were restricted by $2 \mathrm{~L}$ pot size.

The expected progress from selection depends on the heritability, the selection intensity, and the phenotypic standard deviation of the trait (Dudley and Moll, 1969; Simmonds, 1979). In this study, heritability estimates and experimental precision (coefficient of variation) were higher in the first field generation, as compared with the seedling generation for skin texture, shape, overall tuber appearance, uniformity of size, number and average tuber weight (Table 2). These results, however, do not agree with those reported by Silva et al. (2007), who in a study of seedling generation grown in screen-house, verified better expression of genetic variability, probably due to greater environmental effect on the field generation. On the other hand, the results are in agreement in relation to heritability estimates for tuber yield, which was higher in the seedling generation than in the first field generation. It can be ascribed to greater genetic variability in the screenhouse than in the field.

The heritability for skin texture and overall tuber appearance, in the two generations, were higher than estimates reported by Silva et al. (2008), in a study of populations derived from combinations between parents contrasting in skin texture. However, the skin texture estimates were lower than the high values observed by Love et al. (1997), which included parents with extremely rough skin.

The moderately high value estimated for the overall tuber appearance does not agree with low estimates reported by Tai and Young (1984) and Maris (1988).

Heritability estimates for eyebrow prominence, shape uniformity, tuber pointing, and tuber curvature were lower 
than those reported by some other authors (Pinto, 1999; Love et al., 1997; Silva et al., 2008) (Table 3).

Gains expected from selection can be increased by reducing non-heritable variation. In this study, the responses to selection were consistent with the heritability and genetic variance of the trait, in which the traits with higher heritability and genetic variation showed higher expected advances from selection (Tables 2 e 3).

Selection gains expected for the seedling generation are according to Love et al. (1997), which suggested application of light selection for tuber number and tuber yield (Table 2). These authors also concluded that selection should not be applied in the seedling generation for uniformity of tuber size and tuber shape, which are also consistent with the selection gains estimated in this study.

Although larger heritability estimates for skin texture, shape, overall tuber appearance, uniformity of size, tuber number and yield found in this study are in the first field generation, expected responses to selection in the seedling generation were higher, in agreement with the larger genetic variations in this generation (Table 2).

For the average tuber weight, the expected responses to selection were slightly higher in the first field generation than in the seedling generation.

In the process of cultivar development, a breeder looks for generation of populations with high means and wide genetic variability for the traits of interest (Simmonds, 1979). For skin texture, Caesar/C1730-7-94, Pukara/C1730-7-94, Asterix/Eliza, Pukara/C1750-15-95, Rioja/Eliza, Asterix/C-1750-15-95, and Pukara/Eliza families had higher means (smooth) for both generations (Table 2). By grouping family means in every generation, three groups were formed in the seedling generation (Table 2). The families derived from crosses involving 'Pukara' as parent, along with Asterix/Eliza, Asterix/C1750-15-95, Caesar/C1730-07-94, and Rioja/Eliza families formed the top group.

According to Silva et al. (2007), tuber shape is a highly repeatable trait when analyzed between generations, by presenting consistent data. They observed that the genotypes are also grouped similarly in early generations. In this study, there were no differences between generations for this trait (Table 1).

Only the Caesar/Eliza family showed different shape between generations, with rounder tubers in seedling generation. In the seedling generation, the Caesar/Eliza family produced more rounded tubers, while Rioja/C1730-07-94 and Rioja/C1750-15-95 families formed the intermediate mean group in tuber shape. The other families had higher means, i.e., more elongated tubers. In the first field generation it was not possible to separate families in groups (Table 2).

Overall tuber appearance is a very important trait for marketing due to consumer preference (Silva et al., 2008). In this study, all families were superior for overall tuber appearance in the first field generation, which may result from larger tubers in this generation than in the seedling generation, facilitating the visual evaluation (Table 2). In the seedling generation, family means were classified into three groups. The Caesar/Eliza family group had the lowest overall tuber appearance mean, and Rioja/C1730-07-94, Caesar/C1750-15-95, and Rioja/Eliza families formed the intermediate group. Families in which one parent was the Pukara' or 'Asterix', and Rioja/C1750-1595 and Caesar/C1730-07-94 crosses formed the best looking group. In the first field generation, Pukara/Eliza, Asterix/C1750-15-95, Rioja/C1730-07-94, Caesar/Eliza, Caesar/C1750-15-95, Asterix/C1730-07-94, and Rioja/Eliza 
families stood out with the best overall tuber appearance means.

For the uniformity of tuber size, families that included Pukara as a parent and the family derived from Asterix/Eliza cross had higher means in the seedling generation than in the first field generation. In the first field generation it was not possible to differentiate between families, but at seedling generation level it was. Families from crosses including Pukara or Asterix, and the Caesar/C175015-95 family formed the highest mean group, that is, tubers with higher uniformity of size, while the others were less (Table 2).

In relation to the yield traits (tuber number, tuber yield, and average tuber weight), all families had higher means in the first field generation than in the seedling generation. That was expected, given the limited volume of substrate in the pot for the development of tubers. The lower yield of smaller tubers has been reported by some authors as the main difficulty in applying selection in the seedling generation (Brown et al., 1984; Pinto et al., 1999; Gopal et al., 1994; Verissimo et al., 2012). As for the tuber yield, the family means did not show significant differences in the seedling generation, but they did show differences in the first field generation, separating into two groups. Pukara/Eliza, Asterix/Eliza, Rioja/C1730-07-94, and Rioja/Eliza family formed the upper group.

As for the tuber number in the seedling generation, family means were separated into three groups, with those derived from Pukara/C1750-15-95 and Pukara/Eliza crosses stood out with the highest number of tubers per plant, while the smallest mean were obtained by Caesar/C1750-1595 and Caesar/Eliza families. The other families formed an intermediate group. In the first field generation, three groups were formed, and the top group was composed solely by the Asterix/Eliza family, followed by the Pukara/Eliza family group. The other families constituted the lower mean group. The tuber number is an important trait for the seedling generation, since it allows taking a more representative portion to the field, with a larger number of individuals per genotype, providing greater security for selection in this generation.

Regarding average tuber weight, family means were separated into groups in both generations.

Rioja/C1730-07-94, Rioja/C1750-15-95, Asterix/C1730-07-94, Caesar/C1730-07-94 and Rioja/Eliza families formed the group with the highest means in the seedling generation. In the first field generation, four mean groups were constituted, outstanding Rioja/Eliza and Caesar/C1750-15-95 families, followed by Rioja/C1730-7-94 and Caesar/C1730-07-94 families.

For tuber appearance traits, eyebrow prominence, uniformity of tuber size, tuber curvature and tuber pointing there were significant differences only between generations, no being detected differences among families or significant interaction. Although the small tuber size in the seedling generation hinders the visual evaluation of some traits (Verissimo et al., 2012), for eyebrow, tuber curvature and tuber pointing, it was possible to evaluate the tubers for these traits. It is noticed by lower scores, i.e., more tubers with prominent eyebrow, curved and pointed shape in the seedling generation.

Regarding the uniformity of tuber shape, tubers presented higher mean, i.e., more uniform tubers in the seedling generation as compared to the first field generation. Considering the family means for all the traits, Pukara/Eliza, Asterix/Eliza, and Rioja/Eliza families were outstanding.

\section{Conclusions}

Selection can be applied in the seedling generation for skin texture, tuber number and tuber size and overall tuber 
appearance, but with mild to moderate intensity. The largest selection gains are for skin texture, overall tuber appearance tuber, tuber number, tuber yield, and average tuber weight.

\section{Conflict of interests}

The authors declare there is no conflict of interest in the publication of the results of this research.

\section{References}

Bisognin, D.A.; Douches, D.S. 2002. Early generation selection for potato tuber quality in progenies of late blight resistant parents. Euphytica 127: 1-9.

Brown, J.; Caligari, P.D.S.; Mackay, G.R.; Swan, G.E.L. 1984. The efficiency of seedling selection by visual preference in a potato breeding programme. Journal of Agricultural Science 103: 339-346.

Campos, H. de. 1983. Estatística experimental não-paramétrica. $4^{\mathrm{a}}$. ed. Piracicaba, SP: FEALQ, 349p.

Carvalho, F.I.F.; Lorencetti, C.; Benin, G. 2004. Estimativas e implicações da correlação no melhoramento vegetal. Pelotas, RS: Editora e Gráfica Universitária - UFPel, 142p.

Cruz, C.D. 2013. Genes - a software package for analysis in experimental statistics and quantitative genetics. Acta Scientiarum Agronomy 35: 271-276.

Cruz, C.D.; Carneiro, P.C.S. 2006. Modelos biométricos aplicados ao melhoramento genético. Viçosa, MG: UFV, 585p.

Cruz, C.D.; Regazzi, A.J. 2001. Métodos biométricos aplicados ao melhoramento genético. Viçosa, MG: UFV, 390p.

Dudley, J.W.; Moll, R.H. 1969. Interpretation and use of estimation of heritability and genetic variance in plant breeding. Crop Science 2: 257-262.

Gebhardt, C.; Li, L.; Pajerowska-Mukthar, K.; Achenbach, U.; Sattarzadeh, A.; Bormann, C.; Ilarionova, E.; Ballvora, A. 2007. Candidate gene approach to identify genes underlying quantitative traits and develop diagnostic markers in potato. Crop Science 47(S3): S106-S111.

Gopal, J.; Gaur, P.C.; Rana, M.S. 1994. Hereditability intra- and inter-generation associations between tuber yield and its components in potato (Solanum tuberosum L.). Plant breeding 12: 82-83.

Love, S.L.; Werner, B.K.; Pavek, J.J. 1997. Selection for individual traits in the early generations of a potato breeding program dedicated to producing cultivars with tubers having long shape and russet skin. American Potato Journal 74: 199213.

Maris, B. 1988. Correlations within and between characters between and within generations as a measure for the early generation selection in potato breeding. Euphytica 37: 205-209.

Melo, P.E. 1999. Cultivares de batata potencialmente úteis para processamento na forma de fritura no Brasil e manejo para obtenção de tubérculos adequados. Informe Agropecuário 20: 112-119.

Pereira, A. da S.; Daniels, J. (Org.). 2003. O cultivo da batata na região sul do Brasil. Brasília: Embrapa Informação Tecnológica/ Embrapa Clima Temperado, 567 p.

Pinto, C.A.B. 1999. Melhoramento genético de batata. Informe Agropecuário 20: $120-128$

Rodrigues, A.F.S.; Pereira, A. da S. 2003. Correlações inter e intragerações e herdabilidade de cor de chips, matéria seca e produção em batata. Pesquisa Agropecuária Brasileira 38: 599-604.

Silva, G.O.; Pereira, A. da S.; Souza, V.Q.; Carvalho, F.I.F.; Vieira, E.A. 2008a. 
Qualidade de película de famílias clonais de batata. Bragantia 67: 633-638.

Silva, G.O.; Pereira, A. da S.; Souza, V.Q.; Carvalho, F.I.F.; Neto, R.F. 2008b. Seleção para caracteres fenotípicos de tubérculos nas primeiras gerações em batata. Ceres 55: 168-172.

Silva, G.O.; Pereira, A. da S.; Souza, V.Q.; Carvalho, F.I.F.; Neto, R.F. 2007. Parâmetros genéticos em primeiras gerações de seleção em batata (Solanum tuberosum L.). Magistra 19: 98-103.

Silva, G.O.; Pereira, A. da S. 2011. Seleção em gerações iniciais para caracteres agronômicos em batata. Horticultura Brasileira 29: 449-455.

Silva, G.O. da; Ney, V.G.; Pereira, A. da S.; Terres, L.R. 2014. Relações entre caracteres de tubérculo de batata nas primeiras gerações de seleção Revista Ceres 61: 370-376.
Simmonds, N.W. 1979. Principles of crop improvement. New York: Longman, 408 p.

Tai, G.C.C.; Young, D.A. 1984. Early generation selection for important agronomic characteristics in a potato breeding population. American Potato Journal 61: 419-434.

Vencovsky, R.; Barriga, P. 1992. Genética biométrica no fitomelhoramento. Ribeirão Preto, SP: Sociedade Brasileira de Genética, 486 p.

Veríssimo, M.A.; Pereira, A. da S.; Silva, S.D.A.; Terres, L.R.; Ney, V.G.; Silva, G.O. 2012. Expressão e caracteres de tubérculos em função do tamanho de recipiente usado no cultivo de batata na geração de plântulas. Revista Ceres 59: 739-745.

Xiong, X.; Tai, G.C.C.; Seabrook, J.E.A. 2002. Effectiveness of selection for quality traits during the early stage in the potato breeding population. Plant Breeding 121: 441-444. 
Table 1. Joint analysis of variance (mean square) for yield and overall tuber appearance traits, of the seedling generation and the first field generation, of 12 potato families. Pelotas, RS, Brazil, 2015.

\begin{tabular}{lccccccccccccccc}
\hline & & \multicolumn{1}{c}{ Mean square } \\
\cline { 3 - 13 } Source of variation & DF & TEX & EBR & SHA & USH & POI & CUR & APP & SIZ & USI & TBN & YIE & ATW \\
\hline Block & 2 & 0.57 & 0.69 & 0.53 & 0.96 & 1.68 & 0.88 & 0.06 & 0.46 & 0.98 & 0.47 & 759.45 & 3.52 \\
Family (F) & 11 & $1.60^{*}$ & 1.06 & $1.12^{*}$ & 1.21 & 1.34 & 1.28 & 0.14 & 0.84 & 0.98 & $2.87^{*}$ & $811.15^{*}$ & $102.10^{*}$ \\
Generation (G) & 1 & $6.78^{*}$ & $68.83^{*}$ & 1.07 & $29.77^{*}$ & $14.85^{*}$ & $20.37^{*}$ & $106.33^{*}$ & $6.00^{*}$ & $20.16^{*}$ & $74.92^{*}$ & $1042678.7^{*} 30090.13^{*}$ \\
FxG & 11 & $1.96^{*}$ & 1.01 & $1.10^{*}$ & 0.67 & 1.49 & 1.44 & $0.49^{*}$ & 0.84 & $1.48^{*}$ & $1.18^{*}$ & $574^{*}$ & $39.02^{*}$ \\
Error & 44 & 0.38 & 0.78 & 0.48 & 0.88 & 0.76 & 0.83 & 0.09 & 0.45 & 0.77 & 0.20 & 291.34 & 7.15 \\
CVe (\%) & & 12.8 & 12.6 & 12.7 & 14.3 & 10.9 & 11.3 & 9.9 & 11.8 & 14.1 & 10.0 & 10.4 & 7.8 \\
Mean & - & 4.8 & 7.0 & 5.5 & 6.6 & 8.0 & 8.1 & 3.2 & 5.7 & 6.2 & 4.4 & 164.5 & 34.2 \\
CVg/CVe (\%) & & 0.73 & 0.24 & 0.47 & 0.24 & 0.35 & 0.29 & 0.27 & 0.38 & 0.21 & 1.46 & 0.54 & 1.48
\end{tabular}

${ }^{1}$ TEX: skin texture; EBR: eyebrow prominence; SHA: tuber shape; USH: uniformity of tuber shape; POI: tuber pointing; CUR: tuber curvature; APP: overall tuber appearance; SIZ: tuber size; USI: uniformity of tuber size; TBN: tuber number; YIE: tuber yield; ATW: average tuber weight.

* Significant at $5 \%$ error probability by the $\mathrm{F}$ test.

CVe: coefficient of environmental variation. 
Table 2. Means and genetic parameter estimates for tuber overall traits in the seedling generation (G0) and in the first field generation (G1), for 12 segregating potato families. Pelotas, RS, Brazil, 2015.

\begin{tabular}{|c|c|c|c|c|c|c|c|c|c|c|c|c|c|c|c|c|c|c|}
\hline \multirow{2}{*}{$\begin{array}{c}\text { Family } \\
\text { Genetic parameter }\end{array}$} & \multicolumn{2}{|c|}{$\begin{array}{c}\text { Tuber skin } \\
\text { texture }\end{array}$} & \multicolumn{2}{|c|}{$\begin{array}{l}\text { Tuber } \\
\text { shape }\end{array}$} & \multicolumn{3}{|c|}{$\begin{array}{l}\text { Tuber oveall } \\
\text { appearance }\end{array}$} & \multicolumn{4}{|c|}{$\begin{array}{c}\text { Uniformity of } \\
\text { tuber size }\end{array}$} & \multicolumn{2}{|c|}{$\begin{array}{l}\text { Tuber } \\
\text { number }\end{array}$} & \multicolumn{2}{|r|}{$\begin{array}{l}\text { Tuber } \\
\text { yield }\end{array}$} & \multicolumn{3}{|c|}{$\begin{array}{c}\text { Average tuber } \\
\text { weight }\end{array}$} \\
\hline & G0 & G1 & G0 & G1 & G0 & & G1 & GC & & G1 & & G0 & G1 & G0 & G1 & G0 & G1 & \\
\hline Asterix/C1750-15-95 & $6.3 \mathrm{~A} \mathrm{a}$ & $4.3 \mathrm{~B} \mathrm{a}$ & $6.6 \mathrm{~A} \mathrm{a}$ & $5.6 \mathrm{~A} \mathrm{a}$ & $2.4 \mathrm{~B}$ & $\mathrm{a}$ & $4.4 \mathrm{~A} \mathrm{a}$ & 7.0 & $\mathrm{~A}$ a & $5.8 \mathrm{~A}$ & $\mathrm{a}$ & $3.4 \mathrm{~B} \mathrm{~b}$ & $6.0 \mathrm{~A}$ & c $38.4 \mathrm{~B}$ & a $268.0 \quad \mathrm{Ar}$ & $13.0 \mathrm{~B} \mathrm{~b}$ & $844.9 \mathrm{~A}$ & $\bar{A} \mathrm{~d}$ \\
\hline Pukara/Eliza & $6.2 \mathrm{~A} \mathrm{a}$ & $5.1 \mathrm{~B} \mathrm{a}$ & $5.9 \mathrm{~A} \mathrm{a}$ & $5.0 \mathrm{~A} \mathrm{a}$ & $2.0 \mathrm{~B}$ & $\mathrm{a}$ & $4.4 \mathrm{~A} \mathrm{a}$ & 7.3 & $\mathrm{~A}$ a & $5.2 \mathrm{~B}$ & a & $5.0 \mathrm{~B} \mathrm{a}$ & $6.5 \mathrm{~A}$ & b $51.8 \mathrm{~B}$ & a $300.1 \quad \mathrm{~A}$ a & $12.0 \mathrm{~B} \mathrm{~b}$ & $48.3 \mathrm{~A}$ & A d \\
\hline Caesar/C1730-07-94 & $6.1 \mathrm{~A} \mathrm{a}$ & $4.2 \mathrm{~B} \mathrm{a}$ & $6.5 \mathrm{~A} \mathrm{a}$ & $6.0 \mathrm{~A} \mathrm{a}$ & $2.1 \mathrm{~B}$ & $\mathrm{a}$ & $4.0 \mathrm{~A} \mathrm{~b}$ & 6.5 & $\mathrm{Ab}$ & $5.4 \mathrm{~A}$ & $\mathrm{a}$ & $2.8 \mathrm{~B} \mathrm{c}$ & $4.8 \mathrm{~A}$ & c $42.9 \mathrm{~B}$ & a 274.9 A b & $14.9 \mathrm{~B} \mathrm{a}$ & $59.7 \mathrm{~A}$ & $A \quad b$ \\
\hline Asterix/Eliza & $6.1 \mathrm{~A} \mathrm{a}$ & $4.3 \mathrm{~B} \mathrm{a}$ & $5.7 \mathrm{~A} \mathrm{a}$ & $5.3 \mathrm{~A} \mathrm{a}$ & $2.4 \mathrm{~B}$ & $\mathrm{a}$ & $4.1 \mathrm{~A} \mathrm{~b}$ & 7.7 & $\mathrm{~A}$ a & $5.3 \mathrm{~B}$ & $\mathrm{a}$ & $3.9 \mathrm{~B} \mathrm{~b}$ & $7.6 \mathrm{~A}$ & a $39.7 \mathrm{~B}$ & a $327.6 \mathrm{~A}$ a & $11.8 \mathrm{~B} \mathrm{~b}$ & $50.8 \mathrm{~A}$ & A d \\
\hline Pukara/C1730-07-94 & $5.8 \mathrm{~A} \mathrm{a}$ & $4.0 \mathrm{~B} \mathrm{a}$ & $5.8 \mathrm{~A} \mathrm{a}$ & $5.1 \mathrm{~A} \mathrm{a}$ & $2.2 \mathrm{~B}$ & $\mathrm{a}$ & $3.8 \mathrm{~A} \mathrm{~b}$ & 7.6 & $\mathrm{~A}$ a & $5.4 \mathrm{~B}$ & $\mathrm{a}$ & $3.7 \mathrm{~B} \mathrm{~b}$ & $5.7 \mathrm{~A}$ & c $42.1 \mathrm{~B}$ & a 259.7 A b & $12.4 \mathrm{~B} \mathrm{~b}$ & $48.8 \mathrm{~A}$ & A d \\
\hline Pukara/C1750-15-95 & $5.5 \mathrm{~A}$ a & $4.9 \mathrm{~A}$ a & $6.2 \mathrm{~A} \mathrm{a}$ & $5.3 \mathrm{~A} \mathrm{a}$ & $2.1 \mathrm{~B}$ & $\mathrm{a}$ & $4.3 \mathrm{~A} \mathrm{~b}$ & 7.7 & $\mathrm{~A}$ a & $6.1 \mathrm{~B}$ & $\mathrm{a}$ & $4.9 \mathrm{~B} \mathrm{a}$ & $5.4 \mathrm{~A}$ & c $49.4 \mathrm{~B}$ & a 260.8 A b & $11.3 \mathrm{~B} \mathrm{~b}$ & $49.5 \mathrm{~A}$ & A d \\
\hline Rioja/Eliza & $5.2 \mathrm{~A} \mathrm{a}$ & $4.6 \mathrm{~A} \mathrm{a}$ & $5.7 \mathrm{~A}$ a & $5.0 \mathrm{~A} \mathrm{a}$ & $1.9 \mathrm{~B}$ & $\mathrm{~b}$ & $4.6 \mathrm{~A} \mathrm{a}$ & 6.2 & $\mathrm{Ab}$ & $5.9 \mathrm{~A}$ & $\mathrm{a}$ & $3.4 \mathrm{~B} \mathrm{~b}$ & $4.9 \mathrm{~A}$ & c $56.4 \mathrm{~B}$ & a $304.2 \mathrm{~A}$ & $18.2 \mathrm{~B} \mathrm{a}$ & $65,7 \mathrm{~A}$ & A a \\
\hline Rioja/C1750-15-95 & $4.8 \mathrm{~A} \mathrm{~b}$ & $4.2 \mathrm{~A}$ a & $5.0 \mathrm{~A} \mathrm{~b}$ & $5.3 \mathrm{~A} \mathrm{a}$ & $2.1 \mathrm{~B}$ & $\mathrm{a}$ & $4.2 \mathrm{~A} \mathrm{~b}$ & 6.3 & $\mathrm{Ab}$ & $5.6 \mathrm{~A}$ & a & $3.1 \mathrm{~B} \mathrm{~b}$ & $5.1 \mathrm{~A}$ & c $44.8 \mathrm{~B}$ & a 274.7 A b & $15.3 \mathrm{~B}$ a & $55.4 \mathrm{~A}$ & $A \quad c$ \\
\hline Asterix/C1730-07-94 & $4.6 \mathrm{~A} \mathrm{~b}$ & $4.8 \mathrm{~A} \mathrm{a}$ & $5.4 \mathrm{~A} \mathrm{a}$ & $5.8 \mathrm{~A} \mathrm{a}$ & $1.7 \mathrm{~B}$ & $\mathrm{a}$ & $4.6 \mathrm{~A} \mathrm{a}$ & 7.0 & $\mathrm{~A}$ a & $5.8 \mathrm{~A}$ & $\mathrm{a}$ & $3.3 \mathrm{~B} \mathrm{~b}$ & $5.4 \mathrm{~A}$ & c $47.9 \mathrm{~B}$ & a $272.0 \quad \mathrm{~A} \mathrm{~b}$ & $15.1 \mathrm{~B} \mathrm{a}$ & $54.3 \mathrm{~A}$ & A c \\
\hline Caesar/C1750-15-95 & $4.2 \mathrm{~A} \mathrm{~b}$ & $4.5 \mathrm{~A} \mathrm{a}$ & $5.7 \mathrm{~A} \mathrm{a}$ & $4.9 \mathrm{~A} \mathrm{a}$ & $1.8 \mathrm{~B}$ & $\mathrm{~b}$ & $4.9 \mathrm{~A} \mathrm{a}$ & 6.9 & A a & $5.9 \mathrm{~A}$ & $\mathrm{a}$ & $3.3 \mathrm{~B} \mathrm{~b}$ & $4.8 \mathrm{~A}$ & c $40.7 \mathrm{~B}$ & a 282.3 A b & $13.8 \mathrm{~B} \mathrm{~b}$ & $62.9 \mathrm{~A}$ & A a \\
\hline Rioja/C1730-07-94 & $3.7 \mathrm{~B} \mathrm{c}$ & $4.9 \mathrm{~A} \mathrm{a}$ & $4.8 \mathrm{~A} \mathrm{~b}$ & $5.1 \mathrm{~A} \mathrm{a}$ & $1.8 \mathrm{~B}$ & $\mathrm{~b}$ & $4.9 \mathrm{~A} \mathrm{a}$ & 6.0 & $\mathrm{Ab}$ & $6.1 \mathrm{~A}$ & a & $3.6 \mathrm{~B} \mathrm{~b}$ & $5.2 \mathrm{~A}$ & c $50.9 \mathrm{~B}$ & a 305.8 A a & $17,1 \mathrm{~B}$ a & $59.5 \mathrm{~A}$ & $\mathrm{~A} \quad \mathrm{~b}$ \\
\hline Caesar/Eliza & $3.2 \mathrm{~B} \mathrm{c}$ & $4.4 \mathrm{~A}$ a & $3.7 \mathrm{~B} \mathrm{c}$ & $5.7 \mathrm{~A} \mathrm{a}$ & $1.3 \mathrm{~B}$ & $\mathrm{c}$ & $4.5 \mathrm{~A} \mathrm{a}$ & 4.7 & $\mathrm{Ab}$ & $5.8 \mathrm{~A}$ & $\mathrm{a}$ & $2.0 \mathrm{~B} \mathrm{c}$ & $5.4 \mathrm{~A}$ & c $25.2 \mathrm{~B}$ & a 288.2 A b & $9.7 \mathrm{~B} \mathrm{~b}$ & $55.3 \mathrm{~A}$ & A c \\
\hline $\mathrm{CVe}(\%)$ & 16.3 & 5.4 & 17.3 & 3.5 & 16.9 & & 6.6 & 17. & & 4.4 & & 16.2 & 4.9 & 16.2 & 7.7 & 19.9 & 4.9 & \\
\hline$h^{2}$ & 78.2 & 83.1 & 50.1 & 90.3 & 64.5 & & 74.4 & 33. & & 75.1 & & 83.7 & 96.3 & 74.2 & 62.6 & 60.1 & 94.3 & \\
\hline $\mathrm{CVg}(\%)$ & 17.8 & 6.9 & 10.0 & 6.2 & 13.2 & & 6.5 & 7.4 & & 4.4 & & 21.2 & 14.5 & 15.9 & 5.8 & 14.1 & 11. & \\
\hline Mean & 5.1 & 4.5 & 5.6 & 5.4 & 2.0 & & 4.5 & 0 & & 5 & & 3.5 & 5.6 & 44.2 & 284.7 & 13.7 & 54.6 & \\
\hline Gs (\%) & 20.0 & 8.1 & 9.0 & 8.1 & 12.2 & & 7.1 & 5.5 & & 4.90 & & 24.7 & 18.1 & 17.4 & 5.8 & 13.9 & 14.0 & \\
\hline
\end{tabular}

${ }^{1}$ Means followed by the same capital letter in the row and lowercase letter in the column do not differ statistically by the Scott-Knott test at $5 \%$ error probability.

$\mathrm{CVe}$ : coefficient of experimental variation; $\mathrm{h}^{2}$ : heritability; CVg: coefficient of genetic variation; Gs: gain of selection. 
Table 3. Means and genetic parameter estimates for tuber traits in the seedling generation and in the first field generation, for 12 segregating potato families. Pelotas, RS, Brazil, 2015.

\begin{tabular}{lcccccc}
\hline & \multicolumn{5}{c}{ Tuber trait } \\
\cline { 2 - 6 } \multicolumn{1}{c}{ Generation } & $\begin{array}{c}\text { Eyebrow } \\
\text { prominence }\end{array}$ & $\begin{array}{c}\text { Uniformity of } \\
\text { shape }\end{array}$ & Curvature & Pointing & Size \\
\hline First field generation & $8.0 \mathrm{a}^{\mathrm{l}}$ & $5.9 \mathrm{~b}$ & $8.6 \mathrm{~A}$ & $8.5 \mathrm{a}$ & $6.0 \mathrm{a}$ \\
Seedling generation & $6.0 \mathrm{~b}$ & $7.2 \mathrm{a}$ & $7.6 \mathrm{~B}$ & $7.6 \mathrm{~b}$ & $5.4 \mathrm{~b}$ \\
\hline $\mathrm{h}^{2}$ & 49.2 & 32.1 & 34.8 & 43.5 & 61.0 \\
$\mathrm{CVg}(\%)$ & 4.5 & 6.5 & 3.4 & 3.9 & 3.8 \\
Mean & 7.0 & 6.6 & 8.1 & 8.0 & 5.7 \\
Gs $(\%)$ & 3.4 & 4.3 & 1.6 & 2.1 & 6.5 \\
\hline
\end{tabular}

${ }^{1}$ Means followed by the same letter in the column do not differ statistically by the Scott-Knott test at 5\% error probability.

$\mathrm{h}^{2}$ : heritability; CVg: coefficient of genetic variation; Gs: gain of selection. 